\title{
PENGARUH KEPERCAYAAN, KOMITMEN, DAN TEKNOLOGI INFORMASI TERHADAP KINERJA RANTAI PASOKAN (STUDI KASUS IKM PENGOLAH BUAH MARKISA DI KOTA MAKASSAR)
}

\author{
Musran Munizu*)1 \\ *) Departemen Manajemen, Fakultas Ekonomi dan Bisnis, Universitas Hasanuddin \\ Jln. Perintis Kemerdekaan KM. 10, Tamalanrea, Makassar 90245
}

\begin{abstract}
The effective Supply chain management (SCM) has increasingly become an important way to enhance competitive strength as well as business performance. Trust, commitment, and well-integrated supply chain by Information Technology (IT) support are important elements to improve supply chain performance. The objectives of this study are to examine and analyze the effects of trust variables on supply chain performance, trust on commitment, commitment on supply chain performance, information technology on supply chain performance, and effects of trust variable on supply chain performance through commitment variable to Small and Medium Industries (SMIs) of passion fruit processing in Makassar. This study used a quantitative approach, where the questionnaire as main tools for data collection. Data were analyzed by descriptive analysis and partial least square-path modeling (PLSPM). Data computation used SmartPLS 2.0 Software. The results show that trust has a significant effect on supply chain performance, and it also has a significant effect on commitment. Furthermore, commitment has a significant effect on supply chain performance, and information technology has a significant effect on supply chain performance. Trust can improve the supply chain performance by commitment indirectly, and it gives smaller effect on supply chain performance directly than indirectly mediated by commitment. Then, supply chain performance is more influenced by information technology rather than trust and commitment. The results of this study may have implications for the important role of management in maintaining trust, commitment and utilizing information technology in the supply chain system.
\end{abstract}

Keywords: trust, commitment, Information technology, supply chain performance, SMIs of passion fruit processing

\begin{abstract}
ABSTRAK
Pengelolaan rantai pasokan yang efektif telah menjadi cara terbaik untuk meningkatkan daya saing dan kinerja perusahaan. Kepercayaan, komitmen, dan dukungan teknologi informasi merupakan elemen-elemen penting untuk meningkatkan kinerja rantai pasokan dalam suatu perusahaan. Tujuan penelitian ini adalah menguji dan menganalisis pengaruh variabel kepercayaan terhadap kinerja rantai pasokan, pengaruh kepercayaan terhadap komitmen, pengaruh komitmen terhadap kinerja rantai pasokan, pengaruh teknologi informasi terhadap kinerja rantai pasokan, dan pengaruh variabel kepercayaan terhadap kinerja rantai pasokan melalui komitmen pada Industri Kecil dan Menengah (IKM) pengolah buah markisa di Makassar. Penelitian ini menggunakan pendekatan kuantitatif, dimana kuesioner menjadi alat pengumpul data utama. Data dianalisis dengan menggunakan analisis deskriptif, dan partial least square-path modeling (PLS-PM). Komputasi data menggunakan bantuan software SmartPLS 2.0. Hasil penelitian menunjukkan bahwa variabel kepercayaan berpengaruh positif dan signifikan terhadap kinerja rantai pasokan. Kepercayaan juga berpengaruh positif dan signifikan terhadap komitmen. Komitmen mempunyai pengaruh positif dan signifikan terhadap kinerja rantai pasokan. Teknologi informasi mempunyai pengaruh positif dan signifikan terhadap kinerja rantai pasokan. Variabel kepercayaan mempunyai pengaruh positif dan signifikan terhadap kinerja rantai pasokan melalui komitmen. Kepercayaan memberikan efek langsung yang lebih kecil pada kinerja rantai pasokan dibadingkan dengan efek tidak langsung, yang dimediasi oleh komitmen. Kinerja rantai pasokan lebih dipengaruhi oleh teknologi informasi daripada kepercayaan dan komitmen. Hasil studi ini dapat berimplikasi pada pentingnya peranan manajemen untuk konsisten menjaga kepercayaan, komitmen dan pemanfaatan teknologi informasi dalam sistem rantai pasokan.
\end{abstract}

Kata kunci: $\quad$ kepercayaan, komitmen, teknologi informasi, kinerja rantai pasokan, IKM pengolah buah markisa

${ }^{1}$ Alamat Korespondensi:

Email:m3.feunhas@gmail.com 


\section{PENDAHULUAN}

Kompetisi global yang sangat tinggi menuntut adanya hubungan yang kuat diantara para pemasok, proses internal perusahaan dan pelanggan. Integrasi rantai pasokan merupakan salah satu strategi utama untuk meningkatkan kinerja rantai pasokan (Lee et al. 2007). Integrasi yang efektif dapat meningkatkan nilai yang diterima bersama semua anggota dalam suatu sistem rantai pasokan. Selain itu, proses bisnis yang saling terkoneksi dapat meningkatkan kinerja rantai pasokan melalui biaya operasi yang rendah, waktu pengiriman yang pendek, level persediaan yang rendah, dan keandalan perusahaan yang meningkat (Heizer dan Render, 2010).

Manajemen rantai pasok merupakan integrasi proses bisnis, mulai dari kegiatan penerimaan bahan baku, pengelolaan di setiap mata rantai aktivitas produksi sampai siap untuk digunakan oleh pemakai. Proses rantai pasok melibatkan produsen utama, pemasok, produsen, pengecer, dan konsumen (Rajaguru dan Matanda, 2012). Rantai pasok memiliki sifat yang dinamis namun melibatkan tiga aliran yang konstan, yaitu aliran informasi, produk dan uang. Di samping itu, Chopra dan Meindl (2007) menjelaskan bahwa tujuan utama dari setiap rantai pasok adalah untuk memenuhi kebutuhan konsumen dan menghasilkan keuntungan.

Menurut Heizer dan Render (2010) penerapan supply chain management (SCM) yang mengikuti konsep yang benar dapat memberikan dampak peningkatan keunggulan kompetitif terhadap produk maupun pada sistem rantai pasokan yang dibangun perusahaan tersebut. Kunci bagi manajemen rantai pasokan yang efektif adalah menjadikan para pemasok sebagai "mitra" dalam strategi perusahaan untuk memenuhi pasaryang yang selalu berubah. Dalam penerapan supply SCM, perusahaan-perusahaan diharuskan mampu memenuhi kepuasan pelanggan, mengembangkan produk tepat waktu, mengeluarkan biaya yang rendah dalam bidang persediaan dan penyerahan produk, mengelola industri secara cermat dan fleksibel (Pujawan dan Erawan, 2010).

Salah satu hal yang paling penting untuk dimiliki masing-masing perusahaan dalam suatu jejaring rantai pasok adalah kepercayaan antar organisasi (Chopra dan Meindl, 2007). Anderson dan Narus (1990) melihat kepercayaan sebagai keyakinan yang akan memberikan hasil yang positif bagi organisasi. Moorman et al. (1993) menggambarkan kepercayaan sebagai keyakinan atau harapan positif yang diperoleh melalui pertukaran dengan mitra dalam suatu sistem rantai pasokan. Kwon dan Taewon (2004) menyebutkan bahwa kesuksesan pada performa perusahaan (operation performance) dalam supply chain juga berasal dari tingginya nilai kepercayaan dan komitmen yang kuat antar partner dalam supply chain. Pada suatu sistem rantai pasok, proses kemitraan didefinisikan sebagai interaksi antara komitmen, kepercayaan dan kolaborasi antarperusahaan (Ryu et al. 2009). Tingginya tingkat kolaborasi, baik dengan supplier dan pelanggan, mengarah pada perbaikan kinerja (Makara, 2015). Hubungan yang baik dengan mitra dibangun atas dasar kepercayaan. Ahda (2009) mengatakan bahwa keberhasilan melalui kerja sama dicapai melalui peningkatan kinerja perusahaan yang dilandasi dengan hubungan baik.

Hubungan kemitraan, dalam konteks rantai pasok, memiliki orientasi jangka panjang yang lahir dari pendekatan relasional. Cambra dan Polo (2011) menegaskan bahwa hubungan jangka panjang membutuhkan komitmen dari pihak-pihak yang terlibat. Komitmen merupakan motivasi untuk memelihara hubungan dan memperpanjang hubungan. Komitmen harus menjadi sebuah variabel penting dalam menentukan kesuksesan hubungan. Semakin tinggi komitmen yang dibangun dari kepuasan dan kepercayaan maka semakin tinggi kualitas hubungan saluran antara pemasok dan penyalur. Allen dan Meyer (1996) menyatakan bahwa semakin tinggi komitmen yang dapat dibangun baik oleh pemasok maupun penyalur akan memperkokoh hubungan kerja sama yang mereka bangun. Allen dan Meyer membagi komitmen kedalam tiga jenis, yakni afektif, kontinu, dan normatif.

Disamping kepercayaan dan komitmen, informasi merupakan salah satu aspek yang sangat penting dalam pengelolaan rantai pasokan. Dukungan teknologi informasi memungkinkan manajemen dapat mengambil keputusan bisnis secara cepat dan tepat. Kemajuan teknologi informasi dan komunikasi yang termasuk didalamnya adalah electronic data interchange (EDI), dan internet menjadi perangkat penting dalam menangani kompleknya hubungan antara supplier hingga pembeli. Kompleksitas pengelolaan supply chain memaksa perusahaan menggunakan sistem komunikasi secara online. Mengingat peran penting 
dari informasi dalam mendukung kinerja rantai pasok maka manajer harus memahami bagaimana informasi dikumpulkan dan dianalisis (Turban dan Volonino, 2010).

Levi et al. (2004) mengartikan teknologi informasi (TI) sebagai alat-alat, baik berupa perangkat keras maupun perangkat lunak, yang digunakan untuk mengetahui keberadaan informasi dan menganalisis informasi tersebut untuk mengambil keputusan yang terbaik bagi rantai pasok. Chopra dan Meindl (2007) mengistilahkan TI sebagai mata dan telinga, bahkan sebagian dari otak, dari manajemen dalam sebuah rantai pasok yang menangkap dan menganalisis informasi yang dibutuhkan untuk pengambilan keputusan. Levi et al. (2004) mengatakan bahwa tujuan penerapan TI dalam manajemen rantai pasok adalah (a) mengumpulkan informasi mengenai sebuah produk mulai dari produksi sampai pengiriman dan pembelian dan menyediakan pola pandang bagi semua pihak dalam rantai pasok, (b) menyediakan akses bagi seluruh data dan informasi yang ada di dalam sistem melalui satu titik kontak (single-point-of contact). Tujuannya adalah semua informasi yang tersedia baik yang untuk pelanggan atau untuk kebutuhan internal harus dapat diakses dalam satu langkah dan tetap sama terlepas dari cara untuk mengakses data tersebut baik melalui telepon, faks, atau internet, atau siapapun yang membutuhkan data tersebut, (c) menganalisis, merencanakan dan membuat tradeoff berdasarkan informasi dari seluruh komponen dalam sebuah rantai pasok, dan (d) kolaborasi dengan partner untuk mengatasi ketidakpastian, antara lain melalui pembagian informasi untuk mencapai kinerja terbaik.

Turban dan Volonino (2010) mengungkapkan bahwa implementasi pengelolaan supply chain tidak dapat dipisahkan dari perkembangan teknologi informasi(TI). Bahkan kalau dilihat dari sejarahnya, justru kemajuan TI inilah yang melahirkan prinsip-prinsip dasar manajemen rantai pasokan (supply chain management). Hal ini terjadi karena pengintegrasian berbagai proses dan entitas bisnis di dalam manajamen rantai pasokan adalah dilakukannya penggunaan bersama-sama terhadap informasi yang dimiliki dan dihasilkan oleh berbagai pihak dalam suatu sistem rantai pasokan. Selanjutnya, Pujawan dan Erawan (2010) menjelaskan peranan TI di dalam manajemen rantai pasokan dapat dilihat dari dua perspektif besar, yaitu perspektif teknis dan perspektif manajerial. Kedua perspektif ini bersama-sama mendorong pada perbaikan kinerja dan pengambilan keputusan.

Hasil ulasan terhadap literatur menunjukkan pentingnya kepercayaan, komitmen, dan teknologi informasi dalam mendukung kinerja supply chain. Menurut Vorst (2006), kinerja rantai pasok merupakan tingkat kemampuan rantai pasok tersebut untuk memenuhi kebutuhan konsumen. Kinerja rantai pasok merupakan hasil dari berbagai upaya yang dilakukan setiap anggota rantai pasok untuk memenuhi tujuan akhir rantai pasok, yakni kepuasan konsumen. Makara (2015) menemukan kepercayaan memberikan efek yang signifikan terhadap kinerja rantai pasokan. Penelitian Mamad dan Chahdi (2013) mengkonfirmasi bahwa kepercayaan adalah faktor utama kolaborasi anggota rantai pasokan.

Hasil serupa juga ditunjukan Ryu et al. (2009) yang berpendapat selain meningkatkan kolaborasi, kepercayaan (trust) sangat penting dalam membangun komitmen. Perusahaan yang percaya pada integritas mitranya akan memiliki niat yang lebih tinggi untuk melanjutkan kerja sama dengan mitra tersebut (Cambra dan Polo, 2011; Wu et al. 2014). Komitmen dan kepercayaan merupakan faktor utama yang mendukung kolaborasi perusahaan dengan supplier (Stefani dan Sunardi, 2014). Chandra dan Kumar (2000) lebih lanjut mengatakan bahwa kinerja rantai pasokan ditentukan oleh tingkat kepercayaan perusahaan terhadap pemasoknya, dan fleksibilitas organisasi.

Penelitian Zhou dan Benton (2007) menunjukkan bahwa teknologi informasi yang mendukung pertukaran informasi dapat meningkatkan kinerja rantai pasokan. Praktik rantai pasokan dan pertukaran informasi yang efektif merupakan sumber dari perbaikan kinerja rantai pasokan. Selanjutnya, Wu et al. (2014) menyarankan dalam pengembangan rantai pasok, teknologi informasi (TI) merupakan salah satu fasilitator utama keunggulan strategis rantai pasok. Sari et al. (2014) menemukan bahwa dalam memperbaiki kinerja rantai pasok pada petani anggota kelompok tani dan pedagang pengumpul (bandar) yang belum efisien, dapat dilakukan dengan cara melakukan peningkatan nilai output. Hal tersebut dapat dilakukan dengan perbaikan sistem pengiriman, perbaikan pada sistem sortasi dan grading serta perbaikan pada persiapan budi daya ikan lele. 
Kota Makassar telah mengembangkan industri pengolahan buah markisa sebagai salah satu kompetensi inti industrinya. Pengembangan industri pengolah buah markisa di Makassar ditentukan beberapa aspek penting, seperti faktor sumber daya internal, sumber daya eksternal dan kinerja rantai pasokan. Salah satu kelemahan dari IKM untuk berkembang adalah belum optimalnya sistem rantai pasokan yang digunakan dalam proses bisnis (Munizu dan Hamid, 2016). Berdasarkan fenomena dan telaah terhadap literatur maka penelitian ini bertujuan menguji dan menganalisis pengaruh kepercayaan, komitmen, dan teknologi informasi terhadap kinerja rantai pasokan secara langsung. Selanjutnya, menguji pengaruh kepercayaan terhadap kinerja rantai pasokan dimediasi komitmen.

\section{METODE PENELITIAN}

Pendekatan kuantitatif digunakan dalam penelitian ini. Populasi adalah seluruh Industri Kecil dan Menengah (IKM) Pengolah Buah Markisa di Kota Makassar, yakni sebanyak 42 unit (BPS Kota Makassar, 2015). Kriteria IKM mengacu pada BPS, yakni Industri Kecil memiliki tenaga kerja 1-4 orang, sedangkan Industri Menengah memiliki tenaga kerja 5-19 orang. Karena jumlah populasi relatif sedikit dan luas wilayah penelitian relatif dapat dijangkau, maka penentuan sampel dalam penelitian ini menggunakan metode sensus, sehingga jumlah populasi sama dengan besarnya sampel dalam penelitian ini.

Responden adalah manajer/pemilik usaha yang memahami proses bisnis usaha markisa pada perusahaannya. Penelitian ini menggunakan kuesioner sebagai alat pengumpulan data primer, dan dokumentasi sebagai alat pengumpulan data sekunder. Variabel yang diuji hubungannya dalam model terdiri atas: kepercayaan, komitmen, teknologi informasi, dan kinerja rantai pasokan. Variabel kepercayaan, dan teknologi informasi sebagai variabel eksogen, sedangkan komitmen dan kinerja rantai pasokan sebagai variabel endogen.

Variabel kepercayaan diadopsi dan diadaptasi dari penelitian Ahda (2009) terdiri atas empat indikator yaitu komunikasi terbuka, berbagi informasi, kejujuran, dan tanggung jawab. Variabel komitmen terdiri atas tiga indikator, yakni afektif, kontinuan, dan normatif (Allen dan Meyer, 1996). Kemudian variabel teknologi informasi terdiri atas empat indikator, yaitu penggunaan komputer secara efektif dalam operasional, penggunaan internet/website, penggunaan EDI, dan DSS (decision support system) untuk pembuatan keputusan ( $\mathrm{Li}$ et al. 2008). Selanjutnya, kinerja rantai pasokan diukur melalui empat indikator yang didaptasi dari Levi et al. (2004), yakni reliabilitas, fleksibilitas, biaya dan utilitas. Pengukuran variabel dan indikatornya menggunakan Skala Likert 1-5 (Hair et al. 2010; Solimun, 2011). Pengumpulan data dilakukan secara langsung dengan mendatangi responden manajer/ pemilik usaha. Sebelum pengambilan data lapang, maka dilakukan tahapan uji coba instrumen. Validitas diuji dengan Pearson correlation coefficient, sedangkan uji Cronbach's alpha dilakukan untuk membuktikan keandalan atau reliabilitas instrumen atau kuesioner. Setelah dinyatakan instrumen valid dan reliabel maka tahap selanjutnya adalah pengumpulan data lapangan. Dari 42 kuesioner yang disampaikan kepada responden, hanya 38 kuesioner yang terisi secara lengkap, sedangkan empat kuesioner lainnya tidak lengkap dengan tingkat respons sebesar 90,4\%.

Data dianalisis dengan menggunakan analisis statistik deskriptif, dan PLS-PM (Partial Least Square-Path Modeling). PLS-PM merupakan salah satu teknik Structural Equation Modeling (SEM) yang digunakan untuk menguji hipotesis untuk ukuran sampel yang tidak terlalu besar. Pada teknik ini, analisis dilakukan kepada dua submodel, yaitu model pengukuran (measurement model) atau outer model dan model struktural (structural model) atau inner model. Outer model menunjukkan bagaimana variabel manifes merepresentasikan variabel laten yang diukurnya, sedangkan inner model menunjukkan kekuatan estimasi antar variabel laten. Goodness of fit model structural pada analisis PLS berupa nilai predictive-relevance (Q2), yang dihitung berdasarkan nilai koefisien determinasi (R2) masingmasing variabel endogen Adapun nilai predictiverelevance (Q2) diperoleh dengan rumus sebagai berikut:

$$
\mathrm{Q}^{2}=1-\left(1-\mathrm{R}_{1}^{2}\right)\left(1-\mathrm{R}_{2}^{2}\right) \ldots\left(1-\mathrm{R}_{\mathrm{p}}^{2}\right)
$$

Dimana $\mathrm{R}_{1}, \mathrm{R}_{2}$, dan $\mathrm{R}_{\mathrm{p}}$ adalah koefisien determinasi variabel endogen. Besaran nilai $\mathrm{Q}^{2}$ memiliki nilai dengan rentang $0<\mathrm{Q}^{2}<1$, dimana semakin mendekati nilai 1 maka model semakin baik. Besaran $\mathrm{Q}^{2}$ ini setara dengan koefisien determinasi total $\left(\mathrm{R}_{\mathrm{m}}^{2}\right)$ pada analisis jalur (path analysis). Selanjutnya, komputasi data untuk analisis PLS-PM menggunakan bantuan software SmartPLS 2.0 (Solimun, 2011). Adapun 
kerangka konseptual yang diuji pangaruhnya baik secara langsung maupun tidak langsung dapat disajikan secara lengkap pada Gambar 1.

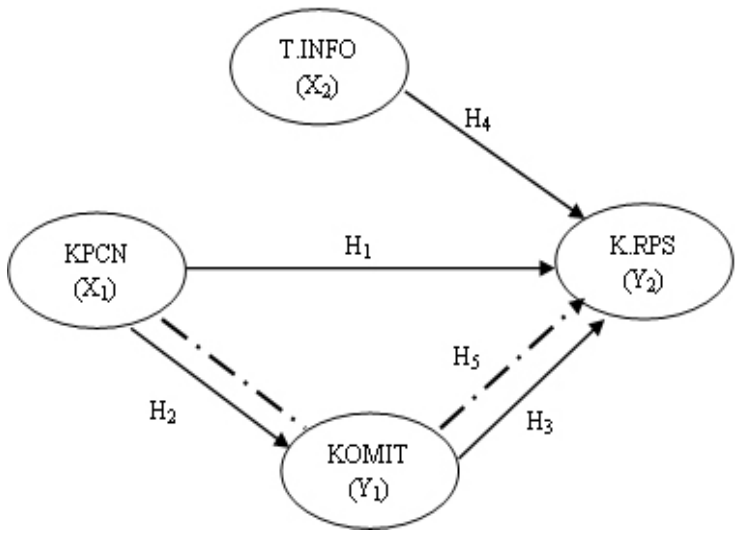

Keterangan:

$\mathrm{KPCN}=$ Kepercayaan; TINFO = Teknologi Informasi; KOMIT $=$ Komitmen; KRPS $=$ Kinerja Rantai Pasokan; H1= Pengaruh X1 terhadap Y2; H2 = Pengaruh X1 terhadap Y1; H3 = Pengaruh Y1 terhadap Y2; H4 = Pengaruh X2 terhadap Y2; dan H5 = Pengaruh X1 terhadap Y2 melalui Y1

Gambar 1. Kerangka pemikiran penelitian

\section{HASIL}

Sesuai dengan hasil analisis deskriptif, maka karakteristik responden dapat dideskripsikan menurut jenis kelamin, umur, tingkat pendidikan, lama berusaha. Hasil analisis deskripsi mengenai karakteristik responden secara lengkap disajikan pada Tabel 1. Berdasarkan jenis kelamin, responden penelitian ini terdiri atas laki-laki 30 orang $(78,95 \%)$, dan perempuan delapan orang $(21,05 \%)$. Dari segi usia, responden dalam penelitian ini paling banyak memiliki usia antara 30-50 tahun (84\%). Kelompok usia tersebut secara teoritis tergolong dalam usia yang produktif. Menurut tingkat pendidikan, responden yang berpendidikan SMU/sederajat, dan sarjana mendominasi, yakni 32 orang $(84 \%)$. Berdasarkan lamanya berusaha, dominan responden telah berusaha selama 11 sampai 20 tahun, yakni 24 orang (63\%). Hasil analisis deskriptif dan PLS dapat diketahui pula nilai rata-rata indikator, loading factor, dan composite reliability instrumen. Hasil pengujian model telah memenuhi kriteria reliabilitas indikator; dimana semua factor loading $>0,50$ kriteria reliabilitas konstruk dengan composite reliability $>$ 0,60 (Hair et al. 2010) seperti disajikan pada Tabel 2.
Tabel 1. Karakteristik responden

\begin{tabular}{|c|c|c|}
\hline Uraian & $\begin{array}{c}\text { Frekuensi } \\
\text { (orang) }\end{array}$ & $\begin{array}{c}\text { Persentase } \\
\quad(\%)\end{array}$ \\
\hline \multicolumn{3}{|l|}{ Jenis kelamin } \\
\hline Laki-laki & 30 & 78,95 \\
\hline Perempuan & 8 & 21,05 \\
\hline Jumlah & 38 & 100,00 \\
\hline \multicolumn{3}{|l|}{ Usia } \\
\hline Di bawah 30 tahun & 4 & 10,53 \\
\hline 30-40 tahun & 20 & 52,63 \\
\hline $41-50$ tahun & 12 & 31,58 \\
\hline Di atas 50 tahun & 2 & 5,26 \\
\hline Jumlah & 38 & 100,00 \\
\hline \multicolumn{3}{|l|}{ Tingkat pendidikan } \\
\hline SMU/Sederajat & 18 & 47,37 \\
\hline Diploma & 2 & 5,26 \\
\hline Sarjana & 14 & 36,84 \\
\hline Pascasarjana & 4 & 10,53 \\
\hline Jumlah & 38 & 100,00 \\
\hline \multicolumn{3}{|l|}{ Lama Berusaha } \\
\hline Di bawah 5 tahun & 4 & 10,53 \\
\hline 5-10 tahun & 8 & 21,05 \\
\hline $11-15$ tahun & 10 & 26,32 \\
\hline 15-20 tahun & 14 & 36,84 \\
\hline Di atas 20 tahun & 2 & 5,26 \\
\hline Jumlah & 38 & 100,00 \\
\hline
\end{tabular}

Berdasarkan Tabel 2, diperoleh nilai Composite Reliability (CR) variabel kepercayaan sebesar 0,767. Hal ini menunjukkan bahwa variabel kepercayaan yang digunakan dalam penelitian ini memiliki tingkat reliabilitas atau keandalan yang sangat tinggi. Hal ini berlaku juga untuk variabel komitmen, teknologi informasi, dan kinerja rantai pasokan dengan nilai $\mathrm{CR}$ masing-masing sebesar 0,$832 ; 0,844$; dan 0,896 .

Dari nilai loading factor dan rata-rata (mean) dapat dijelaskan bahwa indikator tanggung jawab merupakan indikator yang sangat penting dalam membentuk variabel kepercayaan dengan nilai bobot faktor (factor loading) sebesar 0,811 . Sebaliknya, indikator berbagi informasi (information sharing) merupakan indikator yang dipresepsikan tertinggi dengan nilai rata-rata (mean) sebesar 4,05. Pada variabel komitmen, indikator komitmen kontinuan merupakan indikator yang sangat penting dalam membentuk variabel komitmen dan dipresepsikan tertinggi dengan nilai bobot faktor (factor loading) sebesar 0,897 dan nilai rata-rata (mean) sebesar 4,11 . 
Tabel 2. Nilai factor loading, composite reliability, dan rata-rata (mean)

\begin{tabular}{|c|c|c|c|c|}
\hline Variabel & Indikator & Loadings & Composite reliability & Rata-rata (mean) \\
\hline \multirow[t]{4}{*}{ Kepercayaan } & KPCN-1 & 0,559 & 0,767 & 3,84 \\
\hline & KPCN-2 & 0,640 & & 4,05 \\
\hline & KPCN-3 & 0,667 & & 3,95 \\
\hline & KPCN-4 & 0,811 & & 4,00 \\
\hline \multirow[t]{3}{*}{ Komitmen } & KOMIT-1 & 0,659 & 0,832 & 3,84 \\
\hline & KOMIT-2 & 0,897 & & 4,11 \\
\hline & KOMIT-3 & 0,800 & & 3,87 \\
\hline \multirow[t]{4}{*}{ Teknologi informasi } & TINFO-1 & 0,837 & 0,844 & 3,97 \\
\hline & TINFO-2 & 0,813 & & 3,82 \\
\hline & TINFO-3 & 0,806 & & 3,97 \\
\hline & TINFO-4 & 0,559 & & 3,58 \\
\hline \multirow[t]{4}{*}{ Kinerja rantai pasokan } & KRPS-1 & 0,631 & 0,896 & 4,32 \\
\hline & KRPS-2 & 0,883 & & 4,26 \\
\hline & KRPS-3 & 0,930 & & 4,21 \\
\hline & KRPS-4 & 0,843 & & 4,11 \\
\hline
\end{tabular}

Pada variabel teknologi informasi, indikator penggunaan komputer secara efektif dalam operasional usaha merupakan indikator yang sangat penting dan dipresepsikan tertinggi dengan nilai bobot faktor (factor loading) sebesar 0,837 dan nilai rata-rata (mean) sebesar 3,97. Kemudian dapat juga dijelaskan bahwa indikator biaya (cost) merupakan indikator yang sangat penting dalam membentuk variabel kinerja rantai pasokan dengan nilai bobot faktor (factor loading) sebesar 0,930. Indikator reliabilitas merupakan indikator yang dipresepsikan tertinggi dengan nilai rata-rata (mean) sebesar 4,32. Komputasi model dengan menggunakan program SmartPLS 2.0, menghasilkan model estimasi sebagaimana disajikan pada Gambar 2.

Model dikatakan fit apabila didukung oleh data empiris. Goodness of fit model structural pada analisis PLS-PM berupa nilai predictive-relevance $\left(\mathrm{Q}^{2}\right)$, yang dihitung berdasarkan nilai koefisien determinasi $\left(\mathrm{R}^{2}\right)$ masingmasing variabel endogen, yaitu (1) untuk variabel komitmen $\left(\mathrm{Y}_{1}\right.$ ) diperoleh $\mathrm{R}^{2}$ sebesar 0,345; dan (2) untuk variabel kinerja rantai pasokan $\left(\mathrm{Y}_{2}\right)$ diperoleh $\mathrm{R}^{2}$ sebesar 0,501. Adapun nilai predictive-relevance $\left(\mathrm{Q}^{2}\right)$ diperoleh dengan rumus sebagai berikut:

$\mathrm{Q}^{2}=1-\left(1-\mathrm{R}_{1}^{2}\right)\left(1-\mathrm{R}_{2}^{2}\right)$

$\mathrm{Q}^{2}=1-(1-0,345)(1-0,501)$

$\mathrm{Q}^{2}=0,6731$ atau $67,31 \%$
Hasil komputasi model menunjukkan nilai predictiverelevance $\left(\mathrm{Q}^{2}\right)$ sebesar 0,6731. Artinya, model dapat menjelaskan fenomena kinerja rantai pasokan sebesar 67,31\%. Model ini dapat dikatakan memiliki nilai prediktif yang baik sehingga model dapat digunakan untuk pengujian hipotesis. Adapun hasil pengujian hipotesis dapat disajikan pada Tabel 3. Hasil pengujian hipotesis pada Tabel 3, dapat diketahui bahwa 5 hipotesis yang diajukan dalam penelitian ini didukung oleh fakta empiris. Adapun hasil pengujian hipotesis penelitian secara lebih jelas dapat dijelaskan sebagai berikut:

\section{Pengaruh Kepercayaan Terhadap Kinerja Rantai Pasokan}

Pengaruh langsung (direct effect) variabel kepercayaan terhadap kinerja rantai pasokan dapat dilihat dari nilai koefisien jalur (path coefficient) sebesar 0,170 dengan nilai t-statistic yang lebih besar dari nilai t-tabel $(2,045>1,980)$. Hasil ini menunjukkan bahwa hipotesis 1 yang diajukan adalah variabel kepercayaan mempunyai pengaruh signifikan terhadap kinerja rantai pasokan diterima atau didukung oleh fakta empiris. Arah pengaruh memiliki nilai positif dan signifikan yang berarti bahwa kepercayaan yang semakin tinggi diantara anggota rantai pasokan dapat mendorong pada semakin baiknya kinerja rantai pasokan. Hasil penelitian ini konsisten dengan Makara (2015) dan Munizu dan 
Hamid (2016) menemukan kepercayaan memberikan efek yang signifikan terhadap kinerja rantai pasokan. Penelitian Mamad dan Chahdi (2013) mengkonfirmasi bahwa kepercayaan adalah faktor utama kolaborasi anggota rantai pasokan. Berkaitan dengan temuan ini Chopra dan Meindl, (2007) mengatakan bahwa salah satu unsur penting yang harus ada dan tumbuh dalam suatu sistem rantai pasokan adalah kepercayaan diantara anggota rantai pasokan. Selanjutnya, temuan penelitian ini berbeda dengan Stefani dan Sunardi (2014) bahwa tidak ada hubungan antara kepercayaan dengan komitmen.

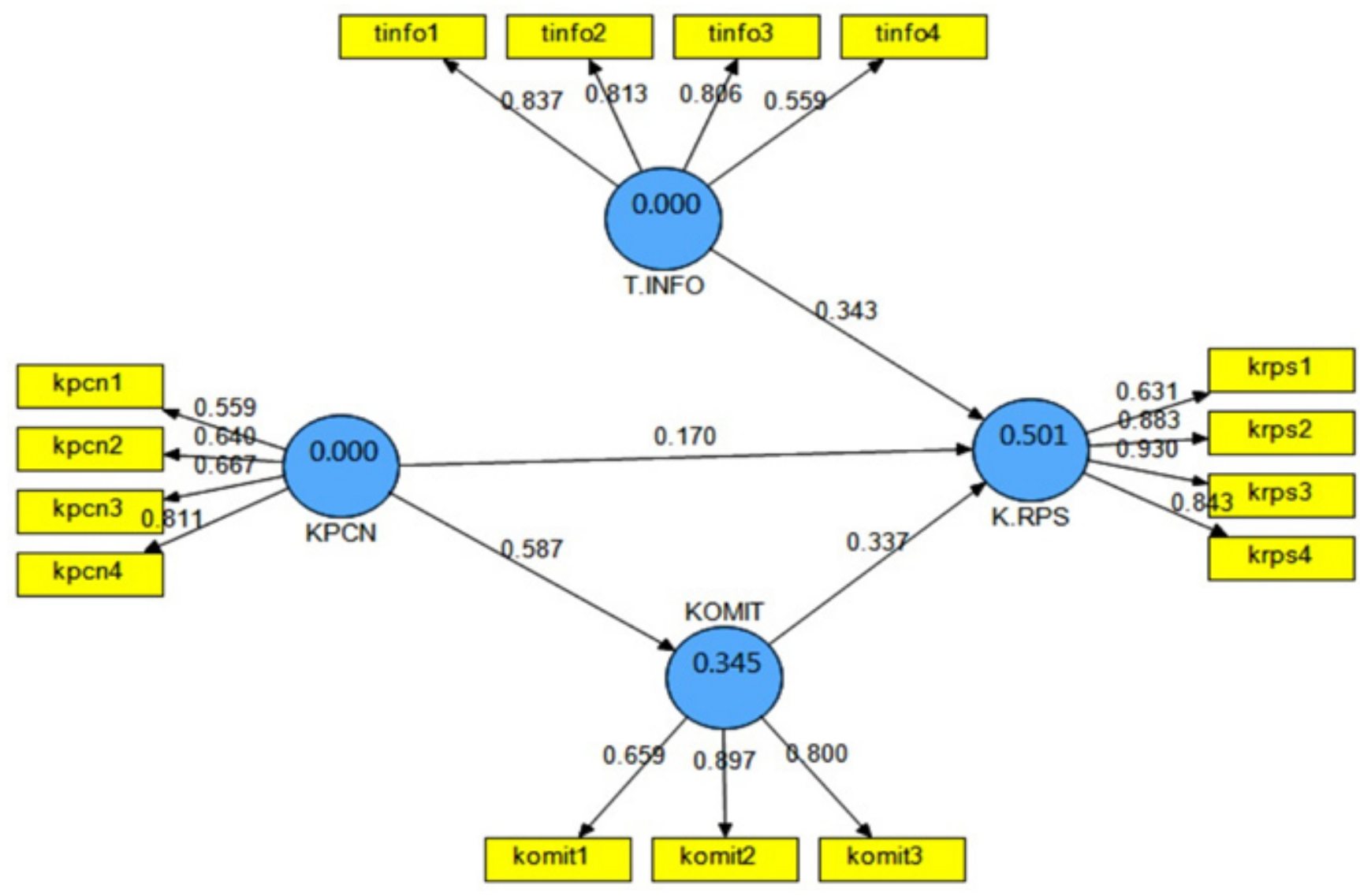

Gambar 2. Hasil Estimasi Model PLS-PM

Tabel 3. Hasil Uji hipotesis penelitian

\begin{tabular}{|c|c|c|c|c|c|c|}
\hline Hipotesis & $\begin{array}{l}\text { Variabel } \\
\text { eksogen }\end{array}$ & $\begin{array}{l}\text { Variabel } \\
\text { endogen }\end{array}$ & $\begin{array}{l}\text { Variabel } \\
\text { mediasi }\end{array}$ & $\begin{array}{c}\text { Path } \\
\text { coefficient }\end{array}$ & T-Statistic & Keterangan \\
\hline \multicolumn{7}{|c|}{ Pengaruh Langsung (Direct Effect) } \\
\hline I & Kepercayaan & Kinerja rantai pasokan & - & 0,170 & 2,045 & Signifikan \\
\hline II & Kepercayaan & Komitmen & - & 0,587 & 8,225 & Signifikan \\
\hline III & Komitmen & Kinerja rantai pasokan & - & 0,337 & 3,884 & Signifikan \\
\hline IV & Tek. Informasi & Kinerja rantai pasokan & - & 0,343 & 5,550 & Signifikan \\
\hline \multicolumn{7}{|c|}{ Pengaruh Tidak Langsung (Indirect Effect) } \\
\hline $\mathrm{V}$ & Kepercayaan & Kinerja rantai pasokan & Komitmen & 0,198 & - & Signifikan \\
\hline
\end{tabular}




\section{Pengaruh KepercayaanTerhadap Komitmen}

Pengaruh langsung (direct effect) variabel kepercayaan terhadap komitmen dapat dilihat dari nilai koefisien jalur (path coefficient) sebesar 0,587 dengan nilai t-statistic yang lebih besar dari nilai t-tabel $(8,225>1,980)$. Hasil ini menunjukkan bahwa hipotesis 2 yang diajukan, yaitu variabel kepercayaan mempunyai pengaruh signifikan terhadap komitmen diterima atau didukung oleh fakta empiris. Arah pengaruh memiliki nilai positif dan signifikan yang berarti bahwa kepercayaan yang semakin tinggi diantara anggota rantai pasokan dapat mendorong pada semakin kuatnya komitmen. Temuan penelitian ini mendukung Ryu et al. (2009) komitmen ditentukan oleh kepercayaan. Selain meningkatkan kolaborasi, kepercayaan (trust) sangat penting dalam membangun komitmen. Perusahaan yang percaya pada integritas mitranya akan memiliki niat yang lebih tinggi untuk melanjutkan kerja sama dengan mitra tersebut (Cambra dan Polo, 2011; Wu et al. 2014). Komitmen dan kepercayaan merupakan faktor utama yang mendukung kolaborasi perusahaan dengan supplier (Stefani dan Sunardi, 2014). Hasil penelitian ini sekaligus mengkonfirmasi dan memperkuat temuan Munizu dan Hamid (2016) bahwa kepercayaan membawa pada terbentuknya komitmen yang kuat pada semua anggota rantai pasokan.

Pengaruh KomitmenTerhadap Kinerja Rantai Pasokan Pengaruh langsung (direct effect) variabel komitmen terhadap kinerja rantai pasokan dapat dilihat dari nilai koefisien jalur (path coefficient) sebesar 0,337 dengan nilai t-statistic yang lebih besar dari nilai t-tabel $(3,884$ $>1,980$ ). Hasil ini menunjukkan bahwa hipotesis 3 yang diajukan adalah variabel komitmen mempunyai pengaruh signifikan terhadap kinerja rantai pasokan diterima atau didukung oleh fakta empirik. Arah pengaruh memiliki nilai positif dan signifikan yang berarti bahwa komitmen yang semakin kuat diantara anggota rantai pasokan dapat mendorong pada semakin baiknya kinerja rantai pasokan. Temuan penelitian ini mengkonformasi sekaligus mendukung temuan Munizu dan Hamid (2016) bahwa komitmen yang tumbuh dengan kuat membawa pada kinerja rantai pasokan yang semakin meningkat. Hasil analisis deskriptif menunjukkan bahwa indikator komitmen kontinuan merupakan indikator yang sangat penting dalam membentuk variabel komitmen dan dipresepsikan tertinggi dengan nilai bobot faktor (factor loading) sebesar 0,897 dan nilai rata-rata (mean) sebesar 4,11. Berkaitan dengan temuan ini Allen dan Meyer (1996) menegaskan bahwa komitmen kontinuan berkaitan dengan keterlibatan secara aktif dan terus-menerus masing-masing individu dalam rantai pasokan untuk menetapkan segala tindakannya bagi perbaikan kinerja semua anggota rantai pasokan.

\section{Pengaruh Teknologi Informasi Terhadap Kinerja Rantai Pasokan}

Pengaruh langsung (direct effect) variabel teknologi informasi terhadap kinerja rantai pasokan dapat dilihat dari nilai koefisien jalur (path coefficient) sebesar 0,343 dengan nilai t-statistic yang lebih besar dari nilai t-tabel $(5,550>1,980)$. Hasil ini menunjukkan bahwa hipotesis 4 yang diajukan, yaitu variabel teknologi informasi mempunyai pengaruh signifikan terhadap kinerja rantai pasokan diterima atau didukung oleh fakta empirik. Arah pengaruh memiliki nilai positif dan signifikan yang berarti bahwa penggunaan teknologi informasi yang semakin baik dapat mendorong pada semakin meningkatnya kinerja rantai pasokan. Temuan penelitian ini konsisten dengan Wu et al. (2014) bahwa teknologi informasi (TI) merupakan salah satu fasilitator utama keunggulan strategis rantai pasok. Mekanisme koordinasi yang baik antara pelaku dalam rantai pasok melalui jaringan informasi online memainkan peran penting dalam meningkatkan efektivitas aliran material, informasi dan uang. Berbagi informasi memainkan peran penting dalam mendukung kemampuan kolaboratif. Selain itu mendukung pendapat $\mathrm{Li}$ et al. (2008) bahwa implementasi TI secara umum diyakini dapat menjadi faktor utama dalam kesuksesan manajemen rantai pasok dan menjadi kebutuhan dalam mengoptimalkan kinerja rantai pasok. Perkembangan teknologi informasi yang pesat mendorong terjadinya integrasi teknologi informasi ke dalam manajemen rantai pasok dan mampu meningkatkan profitabilitas dan efektivitas perusahaan (Marinagi et al. 2014). Teknologi informasi berperan untuk memperkuat kooperasi dan koordinasi dalam rantai pasok, serta dapat menciptakan kesempatan yang lebih baik dalam area rantai pasok, seperti pertukaran informasi, koordinasi, aktivitas integrasi dan sensitivitas. Lee et al. (2007) menegaskan bahwa integrasi pemasok melalui dukungan teknologi informasi dapat meningkatkan kinerja rantai pasokan. 


\section{Pengaruh Kepercayaan Terhadap Kinerja Rantai Pasokan Melalui Komitmen}

Pengaruh tidak langsung (indirect effect) variabel kepercayaan terhadap kinerja rantai pasokan melalui komitmen sebesar $0,198(0,587 \times 0,337)$. Hasil ini menunjukkan bahwa hipotesis 5 yang diajukan, yakni variabel kepercayaan mempunyai pengaruh signifikan terhadap kinerja rantai pasokan melalui komitmen diterima atau didukung oleh fakta empirik. Efek tidak langsung variabel kepercayaan lebih besar dibandingkan efek langsungnya dalam meningkatkan kinerja rantai pasokan. Oleh sebab itu, peningkatan kinerja rantai pasokan harus didahului dengan upayaupaya yang intens dan kontinu oleh manajemen anggota rantai pasokan untuk menciptakan dan menumbuhkan komitmen bersama. Kombinasi antara kepercayaan, komitmen, dan dukungan teknologi informasi akan menghasilkan kinerja rantai pasokan yang lebih baik dalam hal reliabilitas, fleksibilitas, biaya dan utilitas (Heizer dan Render, 2010; Munizu dan Hamid, 2016)

\section{Implikasi Manajerial}

Hasil studi ini berimplikasi pada pentingnya peranan manajemen dalam membangun dan menjaga kepercayaan dan komitmen pada semua anggota (members) dalam sistem rantai pasokan. Selain itu, pemanfaatan teknologi informasi dalam sistem rantai pasokan menjadi hal yang urgen untuk mencapai kinerja yang optimal. Peningkatan kinerja rantai pasokan akan ditandai dengan semakin fleksibel, dan andalnya perusahaan dalam memenuhi permintaan pelanggan. Kombinasi kepercayaan, komitmen, dan penggunaan teknologi informasi akan memberikan hasil yang positif bagi peningkatan kinerja rantai pasokan. Hal ini dapat diamati pada pengiriman produk yang semakin baik (on-time delivery), biaya operasional yang semakin menurun, serta utilitas yang optimal dalam proses operasi atau produksi.

\section{KESIMPULAN DAN SARAN}

\section{Kesimpulan}

Kepercayaan yang semakin tinggi diantara anggota rantai pasokan dapat mendorong pada semakin baiknya kinerja rantai pasokan. Kepercayaan yang semakin tinggi juga dapat mendorong pada semakin kuatnya komitmen anggota rantai pasokan. Komitmen yang kuat dapat mendorong pada semakin baiknya kinerja rantai pasokan. Selain itu, penggunaan teknologi informasi yang semakin baik dapat mendorong pada semakin meningkatnya kinerja rantai pasokan. Implementasi TI secara umum diyakini dapat menjadi faktor utama dalam kesuksesan manajemen rantai pasok dan menjadi kebutuhan dalam mengoptimalkan kinerja rantai pasok. Variabel kepercayaan juga mempunyai pengaruh signifikan terhadap kinerja rantai pasokan melalui komitmen. Efek tidak langsung variabel kepercayaan melalui komitmen lebih besar dibandingkan efek langsungnya dalam meningkatkan kinerja rantai pasokan. Variabel kinerja rantai pasokan lebih dipengaruhi oleh pemanfaatan teknologi informasi dibandingkan dengan kepercayaan dan komitmen.

\section{Saran}

Sesuai dengan hasil kesimpulan studi, maka dapat disarankan kepada manajemen IKM pengolah buah markisa agar dapat memahami secara mendalam pentingnya membangun kepercayaan dan komitmen diantara semua anggota rantai pasokan. Selain itu, penggunaan teknologi informasi sudah menjadi kebutuhan utama bagi perusahaan untuk dapat mengelola dan meningkatkan kinerja rantai pasokan. Peningkatan kinerja rantai pasokan hendaknya didahului dengan upaya-upaya yang intens, terencana dan kontinu oleh semua anggota rantai pasokan untuk menciptakan dan menumbuhkan kepercayaan, dan komitmen secara bersama-sama. Kombinasi antara kepercayaan, komitmen, dan dukungan teknologi informasi yang semakin baik akan menghasilkan kinerja rantai pasokan yang lebih tinggi. Hasil studi ini dapat berimplikasi pada peranan manajemen yang sangat penting untuk menjaga kepercayaan, komitmen dan pemanfaatan teknologi informasi dalam sistem rantai pasokan. Peningkatan kinerja rantai pasokan akan ditandai dengan semakin fleksibel, dan andalnya perusahaan dalam memenuhi permintaan pelanggan. Disamping itu, pada saat yang sama kinerja pengiriman produk yang semakin baik, dan biaya operasional yang semakin menurun, serta utilitas yang optimal dalam proses operasi. Untuk kepentingan penelitian lanjutan disarankan dengan menambahkan variabel, wilayah penelitian yang lebih luas, dan jenis usaha IKM yang berbeda untuk menghasilkan generalisasi temuan yang lebih luas. 


\section{DAFTAR PUSTAKA}

Ahda FA. 2009. Pengaruh bentuk rantai pasokan dan kualitas hubungan perusahaan pemasok dalam mewujudkan kinerja pemasaran melalui peningkatan kinerja rantai pasokan [tesis], Semarang: Program Pascsarjana UNDIP.

Allen NJ, Meyer PJ. 1996. Affective, continuance, and normative commitment to the organization: an examination of construct validity. Journal of Vocational Behavior 49(3): 252-276. https://doi. org/10.1006/jvbe.1996.0043.

Anderson JC, Narus JA. 1990. A model of distributor firm and manufacturing firm working relationships. Journal of Marketing 54(1): 4258. https://doi.org/10.2307/1252172.

BPS Kota Makassar. 2015. Statistik Industri Kecil dan Menengah. Makassar: BPS Press.

Cambra JJ, Polo Y. 2011. Post-satisfaction factors affecting the long-term orientation of supply relationships, Journal of Business \& Industrial Marketing 26(6): 395-405. https://doi. org/10.1108/08858621111156395.

Chandra C, Kumar S. 2000. Supply chain management in theory and practice: a passing fad or a fundamental change?. Industrial Management \& Data Systems 100(3): 100-113. https://doi. org/10.1108/02635570010286168.

Chopra S, Meindl P. 2007. Supply Chain Management: Strategy, Planning, and Operation. New Jersey: Prentice-Hall, Inc.

Hair JF, Black WC, Babin BJ, Anderson RE. 2010. Multivariate Data Analysis, 7th edition. New Jersey: Prentice Hall Inc.

Heizer J, Barry R. 2010. Operation Management. Ninth Edition. Jakarta: Salemba Empat.

Kwon IWG, Taewon S. 2004. Factors affecting the level of trust and commitment in supply chain relationships. Journal of Supply Chain Management 40(1): 4-14. https://doi. org/10.1111/j.1745-493X.2004.tb00165.x.

Lee CW, Ik-Whan GK, Dennis S. 2007. Relationship between supply chain performance and degree of linkage among supplier, internal integration, and customer. Supply Chain Management: An International Journal 12(6): 444-452. https:// doi.org/10.1108/13598540710826371.

Levi DS, Kaminsky P, Levi ES. 2004, Managing The Supply Chain: The Definitive Guide for the Business Professional. USA: McGraw-Hill Inc.

Li G, Yang H, Sun L, Sohal AS. 2008. The impact of IT implementation on supply chain integration and performance. International Journal Production Economics 22: 334-340.

Makara. 2015. Effects of supplier manufacturer relationships on supply chain performance of manufacturing industries in Indonesia. Journal of Technology 19(2): 51-58.

Mamad M, Chahdi FO. 2013. The factors of the collaboration between the upstream supply chain actors: case of the automotive sector in Morocco. International Business Research 6(11): 15-28. https://doi.org/10.5539/ibr.v6n11p15.

Marinagi C, Trivellas P, Sakas DP. 2014. The impact of information technology on the development of supply chain competitive advantage. Procedia Social and Behavioral Sciences 147: 586-591. https://doi.org/10.1016/j.sbspro.2014.07.161.

Moorman C, Deshpande R, Zaltman G. 1993. Factors affecting trust in market research relationships. Journal of Marketing 57: 81-101. https://doi. org/10.2307/1252059.

Munizu M, Hamid N. 2016. How to improve supply chain performance by trust and commitment: study at coffee industry In Makassar, Di dalam: How innovation could improve the performance and productivity in entrepreneurship?. Prosiding International Conference on Entrepreneurship (IConEnt-2016), Tangerang, 17 Maret 2016. Tangerang: Universitas Pelita Harapan. Hlm 559-565.

Pujawan IN, Erawan M. 2010. Supply Chain Management, Edisi-2. Surabaya: Guna Widya Press.

Rajaguru R, Matanda MJ. 2012. Effects of interorganizational compatibility on supply chain capabilities. Industrial Marketing Management Journal 1(2): 220-230.

Ryu I, So S, Koo C. 2009. The role of partnership in supply chain performance. Industrial Management and Data Systems 109(4): 496-514. https://doi.org/10.1108/02635570910948632.

Sari SW, Nurmalina R, Setiawan B. 2014. Efisiensi kinerja rantai pasok ikan lele di Indramayu, Jawa Barat. Jurnal Manajemen \& Agribisnis 11(1): $12-23$.

Solimun. 2011. Analisis Multivariat: Pemodelan Struktural Partial Least Square - PLS, Cetakan I. Malang: Citra Malang Press.

Stefani V, Sunardi O. 2014. Peran dependency, commitment, trust dan communication terhadap kolaborasi rantai pasok dan kinerja perusahaan: 
studi pendahuluan. Jurnal Manajemen Teknologi 13(3): 322-333. https://doi.org/10.12695/ jmt.2014.13.3.6.

Turban E, Linda V. 2010. Information Technology for Management: Transforming Organizations in the Digital Economy, 7th Edition. USA: Wiley Inc.

Wu IL, Chuang $\mathrm{CH}$, Hsu CH. 2014. Information sharing and collaborative behaviors in enabling supply chain performance: a social exchange perspective. International Journal Production Economics 148: 122-132. https://doi. org/10.1016/j.ijpe.2013.09.016.

Zhou H, Benton WC. 2007. Supply chain practice and information sharing. Journal of Operations Management 25(6):1348-1365. https://doi. org/10.1016/j.jom.2007.01.009. 